Л. І. Григор'єва, д.б.н.

Чорноморський національний університет імені Петра Могили, м. Миколаїв

\title{
ЯКІСТЬ ЗРОШУВАЛЬНОЇ ВОДИ: ПІДХОДИ ДО РОЗРОБКИ РАДІАЦІЙНО-ГІГІЄНІЧНИХ КРИТЕРЇ̈В
}

На підставі багаторічних досліджень переходу радіонуклідів зі зрошувальної води та з трунту у сільськогосподарські культури на півдні України висвітлено наявні проблемні питання у технічному регулюванні якості зрошувальних вод за радіаційно-гігієнічним критерієм. Запропоновано визначення радіачійно-гігієнічного критерію якості води для зрошення та визначено фактори, які потрібно врахувати при розробиі радіаційно-гігієнічного критерію.

Ключові слова: радіачійно-гігієнічний критерій, якість зрошувальної води, перехід радіонукліdiв.

Постановка проблеми в загальному вигляді. Оцінка якості зрошувальної води є однією 3 актуальних проблем землеробства у зонах нестійкого і недостатнього зволоження - на півдні України (Запорізька, Херсонська, Миколаївська, Одеська області, Крим). В нинішній час іригаційна оцінка води в Україні проводиться за Державним стандартом України ДСТУ 2730-97 «Якість води для зрошення. Агрономічні критерії» [3] і Відомчим нормативним документом ВНД 33-5,5-12-97 «Якість води для зрошення. Екологічні критерії» [1]. Екологічні критерії регламентуються ще двома стандартами: ДСТУ «Якість природної води для зрошення. Екологічні критерії» [4] і ДСТУ «Якість води для систем крапельного зрошення. Агрономічні і екологічні критерії» [5]. У цих нормативно-технічних документах констатовано, що оцінка якості зрошувальної води за вмістом радіоактивних речовин здійснюється за окремим спеціальним нормативним документом. Однак, як відомо, єдиного НТД 3 оцінки якості зрошувальної води за радіаційногігієнічним критерієм не існує, на що вказують й інші дослідники [14], а така оцінка скоріше за все взагалі не проводиться. При цьому для зрошення на півдні України використовується вода 3 поверхневих водоймищ, яка може бути забруднена радіонуклідами чорнобильського, станційного (через скиди Південноукраїнської та Запорізької AEC) походження, радіонуклідами зі стічних вод Криворізького гірничопромислового басейну, що несе ймовірність перенесення радіонуклідних полютантів у зрошувані сільськогосподарські культури.

Аналіз досліджень та публікацій. У питанні якості зрошувальних вод тільки за останні 20 років накопичений значний науковий матеріал. Це, в першу чергу, стосується токсикологічних показників якості зрошувальної води. Проте багато науково-методичних i прикладних питань усе ще залишаються невирішеними [10 - 12]. Зокрема, слабо розроблені методичні підходи до якості зрошувальної води 3 позицій радіаційної та радіаційно-гігієнічної безпеки, про що йшла мова на нещодавній конференції «Перспективи розширення площ зрошувального землеробства $\mathrm{i}$ забезпечення їх ефективного використання в Південних областях України» [13].

Метою дослідження $\epsilon$ наукове обгрунтування підходів до вироблення радіаційногігієнічних критеріїв оцінки якості зрошувальної води. Робота виконувалась в межах кафедральної НДР $0113 \mathrm{U} 005721$.

Матеріалами досліджень виступали результати радіоекологічних досліджень в агроекосистемах низов'я басейну річок Південний Буг та Дніпро, ставків-охолоджувачів Южноукраїнської (ЮУ АЕС) і Запорізької (ЗАЕС) АЕС, ставківбіоочищення каналізаційної системи ЮУ АЕС, річок Арбузинка, Мертвовід, Інгулець, Інгул, озеро Акташ, Казантипської і Арабатської заток Азовського моря, а також магістральних каналів і водоймищ Інгулецької, Південно-Бузької, Білоусівської, Каховської і Краснознаменської зрошувальних систем протягом 1985-2010 pp. [8, 9], результати інших науковців, проведених в останні роки на території зрошувальних система, які живляться дніпровською водою [12], а також результати наших робіт при розробці подібного нормативно-технічного документу [2].

\section{Завдання дослідження.}

- надати визначення радіаційно-гігієнічного критерію якості зрошувальної води;

- проаналізувати результати спеціально поставленого експерименту з визначення переходу радіонуклідів зі зрошувальної води у сільськогосподарські культури, які наведено у [8];

- проаналізувати результати власних радіаційно-гігієнічних та радіоекологічних досліджень на території зрошуваних масивів півдня 
України [8] 3 позиції критеріїв якості зрошувальної води;

- обгрунтувати фактори, які можуть скласти основу радіаційно-гігієнічного критерію оцінки якості зрошувальної води,

- розробити пропозиції щодо вироблення радіаційно-гігієнічних критеріїв оцінки якості зрошувальної води.

Виклад основного матеріалу досліджень. Базуючись на термінології ВНД 33-5,5-12-97 [2] радіаційно-гігієнічні критерії якості води для зрошення мають встановлювати якість води 3 врахуванням забезпечення радіаційногігієнічного та радіаційно-безпечного стану на зрошуваних масивах та убезпечення зрошувальних вод від радіаційного забруднення. Аналогічним чином оцінку якості води для зрошення за радіаційно-гігієнічним критерієм можна визначити як таку, що проводиться 3 метою попередження радіаційного впливу на компоненти агроекосистеми та забезпечення радіаційної безпеки сільськогосподарської продукції рослинництва, тваринництва, врожаю.

Радіаційну безпеку харчових продуктів, відповідно до Закону України «Про якість та безпеку харчових продуктів і продовольчої сировини» [6], можна трактувати як відсутність загрози радіаційного впливу харчових продуктів, продовольчої сировини та супутніх матеріалів на організм людини. Допустимі рівні вмісту радіонуклідів у харчових продуктах сьогодні контролюються за державним гігієнічним нормативом [7], відповідно до якого величини допустимих рівнів забезпечують не перевищення границі річної ефективної очікуваної дози опромінення населення 1 мЗв за рахунок внутрішнього опромінення від суми радіонуклідів ${ }^{137} \mathrm{Cs}$ та ${ }^{90} \mathrm{Sr}$, що надходять протягом року в організм 3 продуктами харчування та питною водою. Цей нормативний документ був встановлений для врахування радіаційного забруднення територій, обумовленого Чорнобильською аварією: бо саме ${ }^{137} \mathrm{Cs}$ та ${ }^{90} \mathrm{Sr}$ визнані основними дозоутворюючими «чорнобильськими» радіонуклідами. Однак, як відомо, сьогодні існує численна кількість джерел іонізуючого випромінювання, результатом використання яких $є$ потрапляння у навколишнє середовище різноманітних радіонуклідів. Для південного регіону, на території якого радіоекологічні дослідження проводилися нами впродовж багатьох років $[8,9]$, такими джерелами виступають, в першу чергу, атомні електростанції (ЮУ АЕС, ЗАЕС), експлуатація яких супроводжується потраплянням у довкілля «станційних радіонуклідів» (радіоактивні благородні гази: радіоізотопи $\mathrm{Ar}, \mathrm{Kr}, \mathrm{Xе}$; леткі радіоактивні речовини, наприклад, радіоізотопи I, Cs; тритій; неле- ткі радіоактивні речовини, наприклад радіоізотопи $\mathrm{La}, \mathrm{Sr}, \mathrm{Rb}$ та інші) [7]; окремі ділянки, які забруднені радіонуклідами чорнобильського походження внаслідок вітрового перенесення; забруднені води низов'я річок Південний Буг, Дніпро через перенесення з територій водозбору радіонуклідів чорнобильського походження; забруднені води р. Інгулець внаслідок перенесення радіонуклідів з Криворізького гірничорудного басейну.

За результатами спеціально поставленого експерименту 3 визначення $k_{i}^{1}-$ коефіцієнтів переходу радіонукліду ( $i$ - позначення певного радіонукліду) зі зрошувальної води у сільськогосподарські культури [8], отримано ці коефіцієнти для таких станційних радіонуклідів: ${ }^{134} \mathrm{Cs},{ }^{89} \mathrm{Sr}$, ${ }^{106} \mathrm{Ru},{ }^{54} \mathrm{Mn},{ }^{65} \mathrm{Zn},{ }^{110 \mathrm{~m}} \mathrm{Ag},{ }^{58} \mathrm{Co}$.

За результатами багаторічних радіоекологічних та радіаційно-гігієнічних досліджень [8] на території:

- Інгулецької, Каховської і Краснознаменської зрошувальних систем - зрошувальних систем Дніпровського басейну;

- Південно-Бузької, Білоусівської зрошувальних систем - зрошувальних систем Південно-Бузького річкового басейну нами отримано, що кожний зрошуваний масив характеризувався радіаційним станом, який створювався протягом багатьох років і відзначається особливостями, які впливають на накопичення радіонуклідів сільськогосподарськими рослинами. Так, для Інгулецького зрошуваного масиву головним чинником формування радіаційного стану є перенесення 90Sr $з$ течією Дніпра, що обумовило різницю до 10 разів між вмістом радіонукліду у воді цієї та інших досліджених зрошувальних систем, і його сезонними змінами протягом року. Нестабільність вмісту $137 \mathrm{Cs}$ у зрошувальній воді пов'язана 3 більш високим (до 2 разів) вмістом цього радіонукліду у воді р. Інгулець порівняно 3 р. Дніпро. Для Південно-Бузького зрошуваного масиву головними чинниками формування радіаційної ситуації виступали: 1) надходження $137 \mathrm{Cs}$ з забруднених «чорнобильським» 137Cs територій водозбору р. Південний Буг (Вінницька, Хмельницька області); 2) винесення 137Cs до p. Південний Буг з продувними водами ставкаохолоджувача ЮУАЕС; 3) надходження $3 \mathrm{H}$ через фільтрацію та продувку ставка-охолоджувача ЮУАЕС. Основним шляхом надходження радіонуклідів у зрошувальну мережу Білоусівського зрошуваного масиву є фільтрація 137Cs та $3 \mathrm{H} 3$ очисних споруд ЮУ АЕС через підземні води. Розраховані коефіцієнти переходу $90 \mathrm{Sr}$ та $137 \mathrm{Cs}$ у сільськогосподарські культури зі зрошувальної води $k_{i j}^{1}$ (де $\mathrm{i}$ - певний радіонуклід, $\mathrm{j}$ - певний 
зрошуваний масив) та 3 грунту $k_{i j}^{2}$, а $3 \mathrm{H}-$ зі зрошувальної води, свідчили про наявність різниці у 2-3 рази між величинами коефіцієнтів переходу $k_{i j}^{1}$ для $90 \mathrm{Sr}$ та $137 \mathrm{Cs}$ для різних зрошуваних масивів: за 90Sr коефіцієнти $k_{i j}^{1}$ для Інгулецької зрошувальної системи виявилися нижчими за відповідні значення для Південно-Бузької та Білоусівської зрошувальних систем. 3'ясовано, що однією з причин цього $є$ різниця у мінеральному складі води: висока мінералізація води, що надходила до Інгулецької зрошувальної системи, вплинула на перехід 90Sr зі зрошувальної води у сільськогосподарські культури і спричинила зменшенню затримання його культурами. Коефіцієнти переходу $137 \mathrm{Cs}$ у сільськогосподарські культури зі зрошувальної води виявилися вищими для Південно-Бузької та Білоусівської зрошувальних систем. Величини коефіцієнтів переходу $90 \mathrm{Sr}$ та $137 \mathrm{Cs}$ у сільськогосподарські культури 3 грунту $\left(k_{i j}^{2}\right)$ для трьох біогеоценозів характеризувалися меншою різницею і більш близькими між собою показниками. Таким чином, кожний зрошуваний масив відрізнявся шляхами надходження радіонуклідів в агроекосистеми та факторами, які формували радіаційну ситуацію i завдяки яким мала місце істотна різниця між вмістом радіонуклідів у зрошувальній воді трьох зрошувальних систем.

Задля обгрунтування факторів, які можуть скласти основу радіаційно-гігієнічного критерію оцінки якості зрошувальної води, нами проаналізовано ці результати 3 позицій радіаційногігієнічних підходів, тобто не перевищення певних допустимих рівнів. Як вказано вище, величини допустимих рівнів радіонуклідів повинні забезпечувати не перевищення границі річної ефективної очікуваної дози опромінення населення, тому логічно прийняти в якості показника, за яким можна оцінювати безпечність та якість зрошувальної води відносно вмісту радіоактивних речовин, - ефективну еквівалентну дозу Е (Зв), як показник, який використовується в радіаційному захисті та який є мірою ризику виникнення віддалених наслідків опромінення (стохастичних ефектів) тіла людини та окремих його органів і тканин з урахуванням їх радіочутливості.

Ефективну еквівалентну дозу, яку отримує людина від радіонукліду $i$ при споживанні продукції, що вироблена в умовах зрошуваного землеробства (на певному зрошуваному масиві $j$ ),

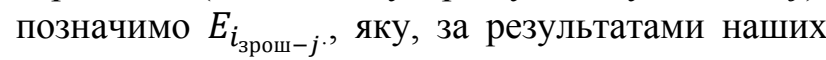
досліджень, у загальній формі можна представити функцією $F$ двох змінних:

$$
E_{i_{\text {зрош }-j}}=F\left(c_{i}, f_{j}\right)
$$

де $c_{i}$ - активність радіонукліду $i$ в джерелі водного забезпечення системи (зазвичай, цим джерелом виступають річкові води), $f_{j}$ - біологічні та фізико-хімічні фактори зрошуваного масиву $j$.

Зрозуміло, що величина $c_{i}$ безпосередньо впливає на $E_{i_{\text {зрош-j }}}$, однак характер цього впливу визначається фактором $f_{j}$. Для визначення цього фактору зроблено деякі припущення і введено наступні позначення: $f_{j}^{1}-$ особливості масиву зрошення (рельєф території, природні стоки, змив 3 території водозбору річок), $f_{j}^{2}-$ особливості грунтів на території зрошення, $f_{j}^{3}-$ фізикохімічні особливості водоймища ( $p H$, мінеральний склад, температура, кількість завислих частинок); $f_{j}^{4}$ - біологічні процеси у водоймищах (поглинання і перерозподіл радіонуклідів між водними компонентами, сорбція-десорбція радіонуклідів мулами, включення радіонуклідів у біологічні цикли та ін.); $f_{j}^{5}-$ інші невраховані фактори.

За результатами проведених нами досліджень можна констатувати, що рельєф території зрошуваного масиву, природні водні стоки та інші гідрогеологічні умови впливають, в основному, на формування радіонуклідного складу води поверхневих водоймищ, які виступають джерелами зрошення, тому їх враховано у показнику $c_{i}$. Грунтовий склад обстежених зрошуваних масивів суттєвого розходження не мав, коефіцієнти переходу радіонуклідів у сільськогосподарські культури з грунту $k_{i j}^{2}$ також мали близькі значення для різних зрошуваних масивів $j$. Тому фактор $f_{j}^{2}$ можна не враховувати. А ось фізико-хімічними особливостями водоймища $f_{j}^{3}$ i біологічними процесами у водоймищах $f_{j}^{4}$ нехтувати не можна:

по-перше, встановлено достатньо істотний вплив мінералізації зрошувальної води на вели-

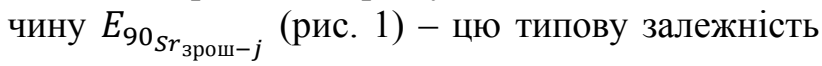
між величиною дози $E_{i_{\text {зрош-j }}}$ та мінералізацією зрошувальної води нами встановлено за матеріалами досліджень на території Інгулецького зрошуваного масиву;

по-друге, визначено, що біологічні та фізико-хімічні процеси, які впливають на перехід радіонуклідів у зрошувальну воду, головним чином, визначаються процесами сорбції $(s)$ і десорбції (des) радіонуклідів мулами водоймищарезервуара, а саме їх відношенням $s /$ des:

1) при переважанні процесу десорбції над процесами сорбції радіонуклідів донними мулами $(s / d s \leq 1)$ відбувається вторинне забруднен- 
ня води в разі переходу сорбованої донними відкладеннями активності у воду;

2) при переважанні процесу сорбції над процесом десорбції радіоактивності в мулах водоймища $(s / d s \geq 1)$ буде відбуватися процес радіаційного очищення води, яка використовується для зрошення, що, відповідним чином, проявляється на зменшенні дози опромінення людини «через зрошення» (рис. 2).

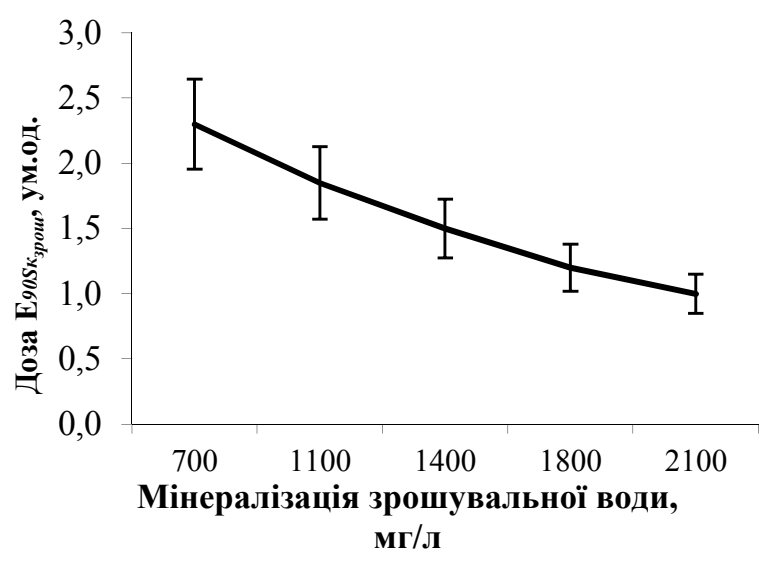

Рисунок 1 - Типова залежність між величиною

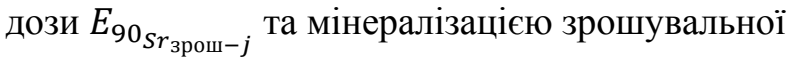
води (за матеріалами досліджень на території Інгулецького зрошуваного масиву)

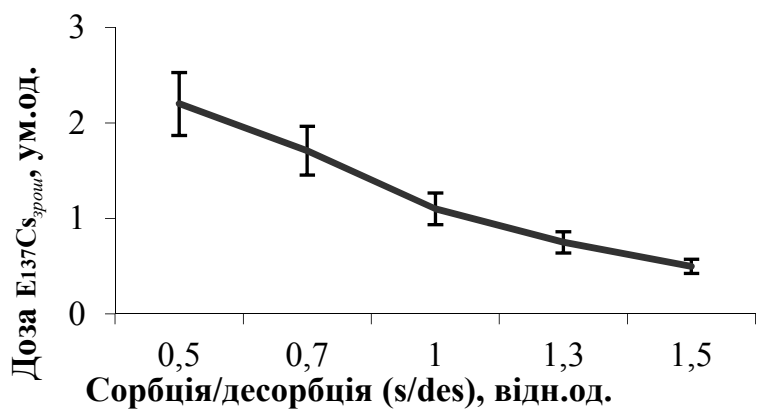

Рисунок 2 - Типова залежність між величиною

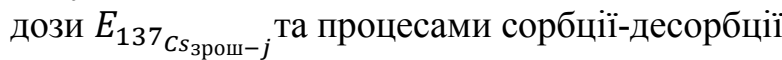
$(s / d e s)$ у водоймищах зрошувальної системи (за матеріалами досліджень на території Білоусівського зрошуваного масиву)

Як відомо, величина відношення $s / d e s$ визначається рівнем $p H$ води та кількістю біотичної складової водоймища: при значній кількості біомаси у водоймищі рівень $p H$ води водоймища зміщується у лужний бік, і, відповідно, вихід сорбованої донними відкладеннями радіоактивності гальмується, а в протилежному випадку, коли середовище водоймища стає підкисленим, можливе серйозна десорбція радіоактивності 3 мулів і вторинне радіаційне забруднення води.
Так, на прикладі аналізу формування радіаційного стану у Білоусівській зрошувальній системі, нами було показано, що неврахування біологічних та фізико-хімічних процесів, які відбуваються у водоймищах зрошувальної системи, приводить до недооцінки величини дози $E_{\text {зром }}$ у 4 рази, а разом 3 неврахуванням регіональних особливостей переходу радіонуклідів у зрошувані сільськогосподарські культури ця величина зростає до 8 разів [9]. Тобто, контролюючи вміст радіонуклідів лише у воді річок, як джерелі насичення зрошувальної системи, можна недооцінити величину навантаження на людину, через неврахування змін у радіонуклідному складі зрошувальної води, які викликані біохімічними процесами у водоймищі-резервуарі зрошувальної системи.

В результаті маємо, що величина дозового навантаження на людину «через зрошення» визначається не лише змінами вмісту радіонуклідів у річковій воді, а також особливостями міграційних процесів радіонуклідів у водоймищахрезервуарах та у біоценозі конкретного зрошуваного масиву. Враховуючи вищевказане (1) набуває наступного вигляду:

$$
E_{i_{\text {зрош-j }}}=F\left(c_{i}, k_{i j}^{1}, s /\right. \text { des }
$$

де $F\left(c_{i}, k_{1 j}, s /\right.$ des $) \epsilon$ функцією, що характеризує радіоекологічний стан конкретного водоймища-резервуара зрошувальної системи. Через те, що величини $\mathrm{c}_{i}$ та $s /$ des $\epsilon$ показниками радіаційного стану води водоймища-резервуару зрошувальної системи $c_{i_{\text {зрош }}}$, а $k_{i j}^{1}$ характеризує перехід радіонуклідів у сільгоспкультури зі зрошувальної води для певного масиву зрошення, то (2.) можна представити так:

$$
E_{i_{\text {зрош-j }}}=F\left(c_{i_{\text {зрош }}}, k_{i j}^{1}\right) \text {, }
$$

Це означає, що при розгляді конкретного зрошуваного масиву $j$, $з$ визначеними коефіцієнтами переходу радіонуклідів у сільськогосподарські культури зі зрошувальної води $\left(k_{i}^{1}=\right.$ const $)$, можна знайти форму залежності дози $E_{i_{\text {зрош-j }}}$ безпосередньо від $c_{i_{\text {зрош }}}: E_{i_{\text {зрош }}}=$ $F\left(c_{i_{\text {зрош }}}\right)$. На рис. 3 зображено типові залежності «зрошувальна вода - доза» для різних зрошуваних масивів $j$. Різниця в «крутизні» ліній, які описують цю залежність для різних зрошуваних масивів, свідчить, що контрольні рівні радіонуклідів у зрошувальній воді будуть також різними для різних зрошувальних масивів і мають розроблятися $з$ врахуванням наведених вище факторів. 

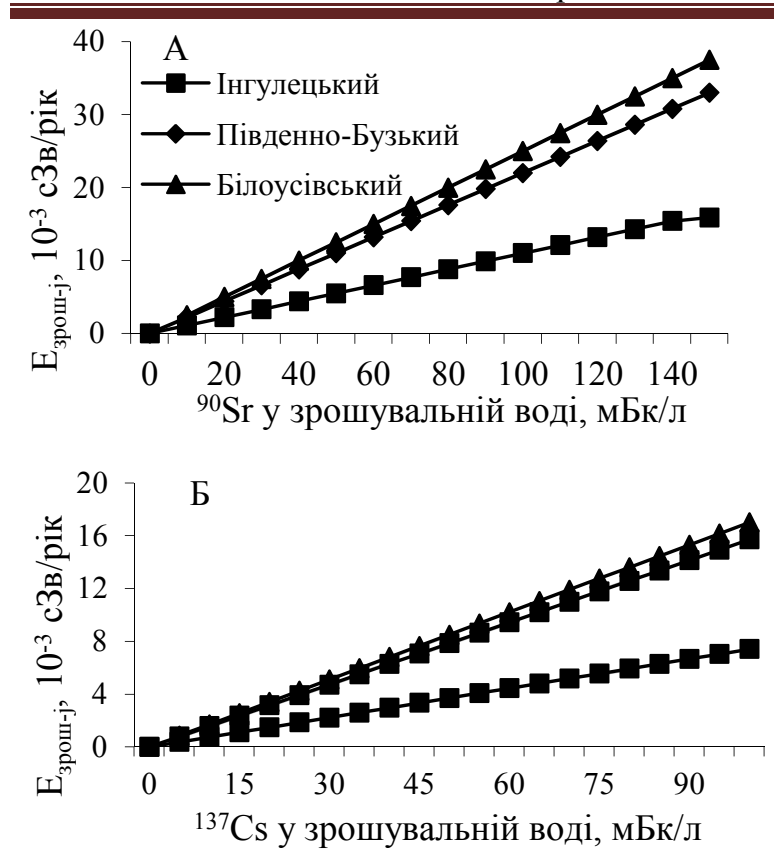

Рисунок 3 - Типові залежності «зрошувальна вода - доза» для різних зрошуваних масивів:

$$
\mathrm{A}-3 \mathrm{a}{ }^{90} \mathrm{Sr}, \mathrm{B}-3 \mathrm{a}{ }^{137} \mathrm{Cs}
$$

Це склало підстави зробити висновок, що при розробці радіаційно-гігієнічного критерію оцінки якості зрошувальної води потрібно враховувати:

- 1) різноманітність шляхів надходження радіонуклідів в агроекосистеми, які визначають величини параметру $\mathrm{c}_{i}$;

- 2) відмінності у характері та інтенсивності накопичення радіонуклідів сільськогосподарськими рослинами зі зрошувальної води - для врахування різних значень коефіцієнту $k_{i j}^{1}$;

- 3) відмінності у характері і інтенсивності накопичення радіонуклідів сільськогосподарськими рослинами 3 грунту - для врахування різних значень коефіцієнту $k_{i j}^{2}$;

- 4) специфіку формування радіаційного стану у водоймищах-резервуарах зрошувальної системи (поглинання і перерозподіл радіонуклідів між компонентами водоймища, осадження на дно водоймищ нерозчинних сполук радіонуклідів і акумуляція їх донними відкладеннями, поглинання радіонуклідів водною біотою, включення розчинних сполук радіонуклідів у біологічний кругообіг водоймища, міграційні властивості радіонукліду та його здатність включатися у біологічні цикли ( $p H$ середовища, солевий склад води, температура, наявність макроаналогів) які впливають на величину параметрів $c_{i_{\text {зрош }}} k_{i j}^{1}$, $k_{i j}^{2}$ та визначають процес сорбції-десорбції радіонуклідів у водоймищі $(S / d e s)$.

\section{Висновки:}

1. Відсутність нормативно-технічного документа для оцінки якості зрошувальних вод за радіаційно-гігієнічним критерієм не дозволяє здійснювати оцінку радіаційної безпеки цих вод, які, при цьому, характеризуються немалою ймовірністю радіонуклідного забруднення.

2. Радіаційно-гігієнічні критерії якості води для зрошення мають встановлювати якість зрошувальної води 3 урахуванням забезпечення радіаційно-гігієнічного та радіаційно-безпечного стану на зрошуваних масивах та убезпечення зрошувальних вод від радіаційного забруднення. Оцінка якості води для зрошення за радіаційногігієнічним критерієм має проводитися 3 метою попередження радіаційного впливу на компоненти агроекосистеми та забезпечення радіаційної безпеки сільськогосподарської продукції рослинництва, тваринництва, врожаю.

3. Показано, що основними факторами, від яких залежить вміст радіонуклідів у зрошувальній воді: радіоактивності води, яка надходить у водоймище $\left(\mathrm{c}_{i}\right)$, мінерального складу води водоймища, який визначає перехід радіонуклідів у сільгоспкультури при зрошуванні $\left(k_{i j}^{1}\right)$, наявності-відсутності вторинного забруднення води через визначення співвідношення процесів сорбціїдесорбції радіонуклідів у водоймищі $(s / d e s)$.

4. Визначено типові залежності, які демонструють формування ефективної дози опромінення людини через споживання нею зрошуваних сільськогосподарських культур від вмісту радіонуклідів у зрошувальній воді для зрошувальних систем, які живляться річковою водою 3 різних басейнів: Південно-Бузького і Дніпровського.

5. При розробці радіаційно-гігієнічного критерію оцінки якості зрошувальної води рекомендується враховувати наступні фактори: різноманітність шляхів надходження радіонуклідів в агроекосистеми; відмінності у характері і інтенсивності накопичення радіонуклідів сільськогосподарськими рослинами зі зрошувальної води, 3 грунту, специфіку формування радіаційного стану у водоймищах-резервуарах зрошувальних систем.

6. Подальші дослідження потрібно спрямувати на розрахунок контрольно-допустимих рівнів радіонуклідів у воді зрошувальних систем 3 врахуванням наведених факторів.

\section{Список використаних джерел}

1. ВНД 33-5.5-02-97. Якість води для зрошення. Екологічні критерії. - Харків, 1998. $15 \mathrm{c}$. 
2. Временные рекомендации по контрольным (допустимым) концентрациям радионуклидов в воде, используемой для полива сельхозугодий в районах АЭС (затверджено $\mathrm{MO} 3$ СРСР 14.01.1988p. і МОЗ України 16.02.1988 р. За № 050606 - 72)

3. ДСТУ 2730-94. Якість природної води для зрошення. Агрономічні критерії. - К.; Держстандарт України, 1994. - 14 с.

4. ДСТУ 7286:2012. Якість природної води для зрошення. Екологічні критерії. - К.: Мінекономрозвитку України, 2013. - 14 с.

5. ДСТУ Якість води для систем крапельного зрошення. Агрономічні і екологічні критерії. К.; Держстандарт України, 2015. - 17 с.

6. Закон України «Про якість та безпеку харчових продуктів та продовольчої сировини» від 06.09.2005 № 2809-IV

7. ГН 6.6.1.1-130-2006 «Допустимі рівні вмісту радіонуклідів ${ }^{137} \mathrm{Cs} \mathrm{i}^{90} \mathrm{Sr}$ у продуктах харчування та питній воді» - Наказ МО3 України від 03.05.2006 № 256

8. Григор'єва Л. І. Радіоекологічні та радіобіологічні аспекти зрошуваного землеробства півдня України. / Л. Григор'єва, Ю. Томілін. - Миколаїв: Видавничий центр МДГУ ім. Петра Могили, 2006. - 264 с.

9. Григор'єва Л. І. Формування радіаційного навантаження на людину в умовах півдня України: чинники, прогнозування, контрзаходи. / Л. Григор'єва, Ю. Томілін. - Миколаїв: Видав- ничий центр МДГУ ім. Петра Могили, 2009. $332 \mathrm{c}$.

10. Козленко Є. В. Вплив умов формування води Інгулецької зрошувальної системи на агрономічні та екологічні показники іiі якості // Зрошуване землеробство: Збірник наукових праць. Херсон: - 2013. - Вип. 56. - С. 164 - 171.

11. Лозовіцький П. С. Наукові основи управління екологічною безпекою зрошуваних земель півдня України: Дисертація на здобуття наукового ступеня доктора технічних наук/ - Київ 2015. $-380 \mathrm{c}$.

12. Майдебура О. П., Вожегова Р. А., Гудков I. М. Міграція радіонуклідів на зрошуваних грунтах півдня України // Зрошуване землеробство: Збірник наукових праць. Херсон: - 2013. Вип. 59. - С.136 - 138.

13. Хуторной О., Рибін В. Майбутнє зрошувального землеробства на Півдні України // Вісник НАН України. - 2015. - № 2. - С. 73, 79 - 80).

14. Якименко А. Н. Оценка качества воды Киевского водохранилища по показателям радиационной безопасности // Химия и технология воды. - 2013. - Т. 35. - № 4 - С. $341-348$.

\section{Надійшла до редакиії 16.09.2016}

Рецензент: д.т.н., проф. Чурсіна Л. А. Херсонський національний технічний університет, м. Херсон.

\section{Л. И. Григорьева, д.б.н.}

\section{КАЧЕСТВО ОРОСИТЕЛЬНОЙ ВОДЫ: ПОДХОДЫ К РАЗРАБОТКЕ РАДИАЦИОННО-ГИГИЕНИЧЕСКИХ КРИТЕРИЕВ}

На основании многолетних исследований перехода радионуклидов из оросительной воды и из почвы в сельскохозяйственные культуры на юге Украины освещены имеющиеся проблемные вопросы в техническом регулировании качества оросительных вод по радиационно-гигиеническому критерию. Предложено определение радиационно-гигиенического критерия качества воды для орошения и приведены факторы, которые необходимо учитывать при разработке этого радиационногигиенического критерия.

Ключевые слова: радиационно-гигиенический критерий, качество оросительной водь, переход радионуклидов

\section{Hrygorieva, DSc}

\section{QUALITY OF IRRIGATION WATER: APPROACHES TO THE DEVELOPMENT OF RADIATION-HYGIENIC CRITERION}

The existing problematic issues in the technical regulation of irrigation water quality on the radiationhygienic criterion were shown based on years of research of radionuclides from the irrigation water from the soil to crops in southern Ukraine. The definition of radiation-hygienic criterion of water quality for irrigation and the factors that must be considered in the development of this radiation-hygienic criterion was invited.

Keywords: radiation-hygienic criterion, the quality of irrigation water, the transfer of radionuclides. 